\title{
DECONSTRUCTION OF THE DIVINITY THEORY IN ISLAMIC THEOLOGY: Philosophical Criticism of Theology as Theoretical Activity
}

\author{
Wahyudin', Suhirman², Hemlan Elhany ${ }^{3}$ \\ ${ }^{1,3}$ State Institute for Islamic Studies (IAIN) Metro Lampung \\ Jl. Ki Hajar Dewantara No.15A, Iringmulyo, Metro Tim., Kota Metro, Lampung \\ E-mail:wahyudinyudi34@yahoo.com; hemlanceraci@gmail.com \\ ${ }^{2}$ State Institute for Islamic Studies (IAIN) Bengkulu \\ JI. Raden Patah, Kelurahan, Pagar Dewa, Selebar, Pagar Dewa, Bengkulu \\ E-mail:suhirman@gmail.com
}

\begin{abstract}
Deconstruction of Devinity Theory in Islamic Theology: Philosophical Criticism of Theology as Theoretical Activity. The doctrine of God in Islam was built as a supreme tradition, in which infiltrate into mankind souls. For centuries, Islam is deemed as an outsider and a threat for western Christian followers. Consequently, any actions are taken to devastate Islam from the earth. Philosophically, this study aims to fortify Islamic theology againts political attacks particularly in separating Muslims from the concept of monotheism. This study employs a critical analysis method, a concept of sharp reasoning to obtain truth. The theory used to reduce metanarrative and elements of deconstruction is the Imre Lakatos research program, in which Islam means conformity or compatibility, harmony and logic. In the core of Islam, monotheism means Allah is One. It has "protective shields" which are the Holy Quran, hadith, and the theory of causality. The results of the study argue that the construction of divinity in Islam is solid and powerful and leads to a failure of criticism.
\end{abstract}

Keywords: deconstruction; philosophical; theological; theoretical; critical

\begin{abstract}
Abstrak: Deconsruksi Teori Ketuhanan dalam Konsep Teologi Islam: Kritik Filsafat Teologi sebagai Aktivitas Teori. Doktrin Ketauhidan dalam agama Islam dibangun di dunia sebagai tradisi agung yang mampu meniupkan ke dalam sanubari manusia. Selama berabad-abad, Islam dipandang sebagai orang lain dan musuh yang berbahaya bagi Kristen Barat. Berbagai carapun dilakukan untuk membenamkan agama Islam dari muka bumi. Filosofis teoretis penelitian ini bertujuan untuk membentengi dari serangan ktitik atas teologi Islam yang di lancarkan terhadap Islam dalam kerangka memisahkan umat Islam dari kerangka ketauhidan. Metode pendekatan menggunakan analisis kritis, sebuah konsep penalaran tajam untuk memperoleh kebenaran. Teori yang digunakan untuk mereduksi metanarasi dan anasir dekonstruksi dengan menggunakan program riset Imre Lakatos. Dalam teori tersebut, terdapat adanya kesesuaian dan keselarasan serta kelogisan dalam agama Islam. Dalam agama Islam, inti program doktrin ketauhidan adalah "Allah itu Esa". Lingkaran pelindungnya, kitab suci Alquran, hadis, serta teori kausalitas, digunakan untuk menghadapi bentuk serangan, kritikan, dan penghancuran. Hasil penelitian dapat diargumentasikan bahwa konstruksi ketuhanan dalam Islam sangat kokoh sehingga berbagai pandangan kritik yang ingin mengubah inti program ketauhidan dalam Islam mengalami kegagalan. Implementasi Inti program dalam Islam tentang tauhid cukup kuat sekali dan mendarah daging sebab diilhami oleh unsur rahmatan lil 'alamîn yang tiada bandingnya.
\end{abstract}

Kata kunci: dekontruksi; filosofis; ketauhidan; teoretis; kritik

\section{Introduction}

The development patterns and the progress of religious thought are always accompanied by revelation toward the transcendent. Revelation can solve the problems faced by every apostle until the development is matured. Allah wants the message of Prophet Muhammad, peace be upon him (PBUH) appeared in this world, therefore, he was sent when the human being experiencing the emptiness of the apostles, to perfect the "building" of his predecessors (the apostles) with the universal and eternal deity, 
and with the book revealed to him, the Quran. In prophetic Islamic theology, Muhammad, PBUH was positioned as the highest among the previous prophets. Muhammad, PBUH was the last prophet and no other prophet came after him. ${ }^{1}$

God does not need additional qualities and values for His perfection but the creatures need and be dependent on the field of being, the divine field and divine attributes for the ride of manifestation. The field is not space. It should not be said that in addition to the space filled with the creature's being, there is a space that places the realities of divine attributes. Godly nature or God's business does not require space. The beings need cultivation, support, hijab or a divine being field to preserve the creature's being to be true, real, continuous and stable. The divine nature is also required by beings to protect them from Allah's Swt revelation, for example "do not you have the right to be happy, calm and confident with His promise if you know that the perfect and the Wise Rabb"2.

The nature of the transcendent reality is supra as well as inter-cosmos, personal and impersonal, lahut and nashut, creatures and God, dear and evil, vanish and eternal, visible and abstract and other dichotomic properties. Man is the revelation or mirror of asma and the properties of absolute reality, the mirror of asma and His diverse nature. Therefore, the existence of the cosmos which is said to be the creation is essentially the unfolding of asma and His eternal nature. ${ }^{3}$

If the creatures receive God's Swt revelation, they will be destroyed and lost vanish. The divine attributes become a hijab that firmly protects the creatures and saves them. The non-existent embodiment of the hijab protecting is the realization of the creation of an eye-mistaken expert. The creation of an eye-mistaken expert is unstable, unrighteous, and does not survive its existence. God's creation, which is exalted

\footnotetext{
${ }^{1}$ Almakin, Nabi-nabi Nusantara Kisah Lia Eden dan lainnya, (Yogyakarta Suka Press, 2017), p.3.

2 Aidh al- Qarni, La Tahzan, Jangan bersedih, (Jakarta, Qisthi Pres, 2014), p.310.

${ }^{3}$ Abdul Razak and Rosihan Anwar, Ilmu Kalam untuk UIN, STAIN PTAIS (Bandung:Pustaka Setia, 2001), p.36.
}

by divine attributes, is stable, true and eternal to the Hereafter. The divine hijab which holds the existence of a creature, which is in relation to the creature, is the attribute of God that He permits to be attributed to Him. His unspeakable attributes are his essential nature. The aspect of God that may be dubbed and said is called tasybih and should not be called tanzih. "Nothing is equal to Him" is the aspect of tanzih. "and He hears and sees" is the aspect of tasybih. The perfect makrifat is knowing God in the aspects of tasybih and tanzih at the same time.

Al-Kindi points out that Godtruly exists. This existence does not mean that $\mathrm{He}$ is originally inexistent but then exists. It is always impossible that $\mathrm{He}$ is inexistent. He is always there and will always be there. Therefore God is a form of perfection that is not preceded by another being, does not end in its form and there is no form except with Him. ${ }^{4}$

By listening to Al-Kindi's opinion that God is the essence that created the universe, which is omnipotent and regulates everything. There is something that resembles $\mathrm{Him}$ and He does not need to His creatures. God is the One Essence. One means not only concentrated on His own essence. God does not feel the pain as what the creatures feel, not hungry and not sleepy and tired, because these all are created by God as the creatures' destiny. The essence that already covers the things mentioned above means worthy of God.

Destruction God's nature with creatures: there is someone who is carried overly high in imagination and gives the nature and state of creature to a God. For example: "Does God have the power to create a stone that is too heavy, unable to be lifted by Himself?" shows the desire to put human nature to God. Heavy is a law created by God, what is heavy on earth does not mean heavy in the sky. And the weight does not work in the unseen world, whereas God himself is His strength/ability beyond everything and the creator of everything including space and the unseen world.

${ }^{4}$ Hanafi, Pengantar Filsafat Islam, (Jakarta: Bulan Bintang, 1969), p. 85. 
In this modern and multi-technological era, the enrichment of divinity is more extreme caused by the advancement of the level of human thinking accompanied by advances in the field of technology. So the question of divinity in the realm of the microcosm is no longer merely tawheed but penetrated to the procedure of practice in mankind and God the Almighty. All Muslims agree on God's self-dignity, as well as Christians say about God's even orientalism. The difference is the implementation of religious practices towards different tawheed, this is where the estuaries of theology (deity) of the critics of theology arise.

\section{Method}

This study is philosophical literature research of which method is critical analysis. This critical analysis gives an attempt to test the thinking and understanding the doctrinal content. ${ }^{5}$ The critical method, as revealed by Plato in the dialogue, is critical to discover the truth. ${ }^{6}$

Critical analysis with details and opinions by continually asking questions to the fact that they are asked.7 Critical analysis to understand the Islamic religion is seen as others and dangerous enemies. Theoretically, from outside of Islam is a variety of ways made to immerse Islam from the world. Researchers then filed philosophical criticism of the theoretical activity used by Islamic outsiders that would destroy Islam. Researchers in philosophical criticism use the theory of deconstruction of the program, research Imre Lakatos in order to fortify and defend the doctrines of the Islamic theology from outside Islam attacks. Philosophical criticism as a theoretical activity to prove a universal and fundamental truth about Islamic theology is unshakable.

${ }^{5}$ Anton Bakker and Achmad Charris Zuberi, Metodologi Penelitian Filsafat, (Yogyakarta: Kanisius, 1990), p.110

${ }^{6}$ Anton Bakker, Metode-Metode Filsafat, (Jakarta, Ghalia Indonesia, 1984), p.25.

7 Louis O Kattsof, Pengantar Filsafat, (Yogyakarta: Tiara Wacana Yogya,1996), p.18. Original book: Elements of Philosophy, North Carolina University U.S.A. The Ronald Press Company New York, translated by. Soejono Soemargono.

\section{Understanding God}

For those who believe, God is essential in their daily life. It includes the meaning that God is praised to bless them. ${ }^{8}$ Syaikhul Islam Ibn Taimiyah gives the definition of al-ilâh (God) as follows: al-ilâh is: who is adored with great love; bowing to Him, humbling himself before Him, fearing and expecting $\mathrm{Him}$, a place of resignation when in difficulty, praying and putting his trust in Him for his own good, pleading for His protection, and creating a calm in remembering $\mathrm{Him}$ and being in love with Him. ${ }^{9}$

Certainly, humans are unlikely atheists including communists. Based on the logic of the Quran, for every human being, there must be something to which he is held. Thus, the communists essentially believe in God as well. Their god is their ideology or dream (Utopia), which is the creation of "communist society, where everyone can work according to their own ability and earn income according to their individual needs", as clearly formulated by their leader, Lenin, in his communist manifesto: "From everyone according to his ability, and for everyone according to his need." This phrase is translated by the leaders of the late PKI (Indonesian Communist Party) with the slogan: "equally as

${ }^{8}$ In the book “Menyingkap Rahasia Isra'-Mi'raj Rasulullah Saw", by Abddullah Zakiy Al-Kaaf, taken from Qishatul Mi'raj dan Al-Mi'rajul Kabir from syeh Najamuddin Al-Ghaithy, Publisher Al-Babi Al-Halabi wa Aulaaduh- Mesir 1347 and republished in Indonesian in 2012 Pustaka Setia Bandung p. 517. For example, if God can be sen there (Arasy), does it means that He stays there? This is not true. God does not need a dwelling place as humans or other beings. God is glorified from supposition by man. The simple proposition is when you meet someone on a train, whether his or her home is there. Only people who do not think that will answer Yes. if so where is the place of God Almighty? Allah knows (only God knows). God is worshiped as a theological concept of something that is considered important by man, in the book Prophetic Intelligence of prophetic intelligence, cultivate the essential potential of insane through the development of spiritual health by Hamdani Bakran Adz-Dzakiey, Yogyakarta: Banguntapan Bantul, 2013, p. 80. Explained, in essence, the attributes of Allah Swt as well as its names are infinite, infinite and not in equal with anything. The names of god's character are all very sacred entrances to enter the oceans his perfection, his blessings, his blessings. through the light of His names, His attributes will be the glow of His Essence, whoever has been guided and led to those lights, he will be amazed and fascinated with the beauty, the fragrance of the name and His gentleness

9 Yusuf Qardawi, Tauhid dan Fenomena Kemusyrikan, Haqiqat Al-Tauhid translated by. H. Abd. Rahim Haris, (Jakarta: Pustaka Darul Hikmah, 2001), p. 26. 
taste". Communists are actually dreaming of creating a "just perfect" economic society. ${ }^{10}$

What a great question mark for every Muslim who believes in the perfection of his scriptures. Could God have "forgotten" to mention this fact, so the Quran does not mention the atheist and atheism at all. Q.S al-Insân [76]: 30. "And ye are not able (to go the way), except when Allah wills. Verily Allah is the Exalted in Might, the Wise"."1 The word "god", which is always translated as "god". In the Quran is used to declare various objects, which are raised or humanized. For example, in Surah al- Jâtsiyah [45]: 23 and Surah al-Furqân [25]: 43. "Have you not noticed how human beings give up their personal desires.

Human perception cannot attain sufficient knowledge of the original source of the matter, who knows the absolute principle of the identity of thought and existences God because God is the absolute unit or identity of thought of existence. God is a unit of no bear and no time, while the world is a plurality of time spaces. Religion is not a rational verification of the act of worship and is merely a moral act.

Giving the name of God in the understanding of Muslims and Christians in Indonesia, God used to be called Allah. The word is derived from the Arabic language derived from the word "al" which is synonymous with "the" in English and the word "Illâh" (God). Literally, Allah means one and one God. Whereas in the belief of the Hindu, God is given the title of Brahma or Sanghyang Widhi Wasa and in the Buddhist literature of God it is Atthi Ajatan Abhutan Akatan Sam Khatan that means something not born, not in the incarnate, not created and the Absolute. ${ }^{12}$ Thus God cannot be personified and cannot be described in any form, in the presence of an unconditioned; the conditioned human being can encapsulate the freedom of his life circle by means of meditation. ${ }^{3}$ The paradigm of theology in the concept of

${ }^{10}$ Yusuf Qardawi, Tauhid dan Fenomena Kemusyrikan..., p. 27

${ }^{11}$ The Ministry of Religious Affairs Republic of Indonesia, Alqur'an dan terjemahannya, (Jakarta: Yayasan Penerjemah, 1974), p.106.

${ }_{12}$ Antonius Atosokhi Gea et al., Relasi dengan Tuhan, (Jakarta: Elex Media Komputindo, 2004) pp.1- 46.

13 Cornelis Wowor, Ketuhanan Yang Maha Esa dalam Agama Budha, (Jakarta: Akademi Buddhis Nalanda, 1984)
Islam is the rahmatan lil 'âlamîn religion for all human beings and all creatures, wishing for the love of God. ${ }^{14}$

\section{Theory of Divinity}

Some people think that they are clever, so they do not need Gods. They say that they do not need to be something that cannot be proven. They also refuse to say, atheist. They call themselves agnostic. One of the most prominent figures of agnostics was the Bertrand Russell, the English philosopher, who had been invited with the honor of lecturing at universities in the United States in the early forties. His lectures have sparked the outrage of American Christian figures, especially Bishop Manning of the Episcopal Church, for being "very contrary to religion and moral values". Indeed Russel argued that "all religions in this world, Buddhism, Hinduism, Christianity, Islam, and Communism" are false and dangerous "("I think all the great religions of the world Buddhism, Hinduism, Christianity, Islam, and Communism are untrue and harmful"), therefore he opposes all religions. ${ }^{15}$

What very interesting is that, similar to Toynbee, Russell also considers communism as a religion. If we read his famous book: "Why I Am Not a Christian", then it can be stated that he is a godly figure as well. Russell, in essence, has been deifying his mind. As long as he can be consistent, it's still pretty decent, especially when compared to the person who lusts his lust. But,

${ }^{14}$ In Hamdani Bakran adz-Dzakiey'S book, Psikoterapi dan counseling Islam, Yogyakarta; Fajar Pustaka baru, 2001, p.4, it is described that every creature named human is essentially planted in their heart a holy light which always longs to meet God and His love. The tendency of holiness always wants to be straight, good, honest and true because the very nature of man is above divine purity. The holiness will never change until whenever. However, because the place whereof the nature of light resides is deeply hidden behind the deepest pure heart, so very few people know it. As explained by Hamdani Bakran Adz-Dzakiey's book Prophetic Intelligence, p. 44 Humans have the potential to stay away and Ulûhiyyhah is the ability to behave and the strong belief that the All-powerful and the dependability of all beings to Allah Almighty Allah who is Wajib al-Wujûd. If attitudes and beliefs are in training and developed properly and correctly, it will give birth to spiritual intelligence. Through this intelligence, a person will be able to play a degree, hold dialogue, face to face and will understand the nature of the transcendental nature.

${ }^{15}$ Muhammad 'Imaduddin dan 'Abdulrahim, Kuliah Tauhid, (Bandung: Pustaka-Perpustakaan Salman ITB, 1980), p. 7. 
it is possible that someone is always consistent.

Based on the definition of "ilâh" or god that has been given the definition above, it can also logically be proved that no human being is able to think logically, is godless. It can even be proven, that it is impossible for humans to have no beliefs. When someone says: "I do not believe in anything, it will be confronted with a contradiction, because it contains self-annihilation, and if he does not believe in anything, then he must deny the truth. The character still has one belief that is the truth of that statement, the attitude is also contrary to the meaning of the sentence so the sentence is illogical, and cannot be uttered by someone who is capable and willing to think logically. The more complete form of ilâh, according to the writer, is lâ ilâhaillallâh. ${ }^{16}$

According to Father Wilhelm Schmidt who once worked in Flores, the divine presence in the original religiosity of the whole of nature is infused by invisible powers, such as floods, droughts, fallen trees of any wild beasts that infect humans, exposing those invisible forces. ${ }^{17}$ The view of the original java world understands nature as two dimensions, birth dimension, an inner dimension. The dimension of birth is natural, but nature is only understood from the inner dimensions of the powers that lie behind it. This natural appreciation is that there is no separation between nature and the Divine.

As occurred in Hinduism, even though there are many God names given, the phenomena are

${ }^{16}$ In this divine theory, Muhammad Qutub describes in a book entitled, Koreksi atas Pemahaman La llahalla Allah, translated by. Yudian Wahyudi Asmin, (Yogyakarta; al-Kautsar, 1989), p.36. will eliminate severe physical mood, moral corruption due to khamar, gambling, adultery, burying adultery of girls, robbery, coercion and social tyranny. This sentence will also cleanse the soul, soul, feeling and human behavior in total. It is also explained in Hamdani Bakran Adz-Dzakiey book Prophetic Intelligence, p. 501. Verily, having successfully entered the essence of Lâ ilâha Allâh means that he has been mortal and eternal with God. At once open the door of his surge, because the sentence is the key to that paradise. Enter yourself into His 99 Heavens like Jannâtur Rahmân, Jannâur Rahîm, Jannâtul Malik, Jannâtul Qudûs, Jannâtul Salâm, Jannâtul Mu'în and so on. So, if it has succeeded with the zikr of Tawheed sentence, it means entering the pronunciation of Allah and the presence of the essence of His name in the self that will be implemented in every act, behavior, and attitude automatically without forcing and being forced

17 Franz Magnis Suseno, Menalar Tuhan, (Yogyakarta: Kanisius, 2006), p. 12. in terms of functions and duties. Thus Sanghyang Widhi is called Brahma at the time of the creation of the universe with all wisdom, called Vishnu at the time he kept all of his creation with love. And it is called Shiva when he returns all His creation to His origin. ${ }^{18}$ It is explained a theory of divinity in Buddhism. ${ }^{19}$

The philosophy of Islam also follows the conception of Aristotle, namely that God is a substance that thinks and becomes the object of His thought (aqil and ma'qul) because of His own substance. Yet he does not recognize the number (plurality) of him with all his commandments. The philosophy of Islam explains the nature of God with a clear description. He is explained as the first being and the real cause of all its existence and events, holy of allies and comparisons. He is the One and Only God, alive, powerful, allknowing, all-wise, and all-hearing. ${ }^{20}$

God puts himself above the image and the image awakens God's mind in the worshippers. A piece of plain white paper or plain colored paper has no value and we will dump it. The resurrection of the Godhead acts as a guardian angel who blesses all and gives the highest good

\footnotetext{
${ }_{18}$ Cundamani, Bagaimana Umat Hindu Menghayati Ida Sanghyang Widhi, (Jakarta: Department Agama RI, 1990) p,11

${ }_{19}$ Antonius Atosokhi Gea et al., Relais dengan Tuhan, (Jakarta: Elex Media Komputindo, 2004) p. 120. For the Buddhist Prayer, a hope expression is not asking. Without doing business, praying in this regard is considered not enough to guarantee someone who does so can achieve its goal. Buddhists will never force anything on God. God is not a person or being that is a place to live or ask for. It is also expressed by Mettadewi, in a book entitled Buddha Dharma As the Living Guide (Jakarta: Pancaran Foundation, 1992), p.37 which explains that Buddhists should not be dragging the gods to engage in this mundane worldly matter. What is really to be done as a Buddhist is to clear the mind of the dirt soul. The mind is not visible, it is smooth and slippery, therefore very difficult to follow and difficult to control. For that first step is to control speech and deeds. An easy way to do this is to live good habits such as performing ceremonies or worship services. Also stated by Krisnanda Wijaya-Mukti, in the book Wacana Budda-Dharma (Jakarta: Foundation Dharma Development, 2003), p. 94. Kristian opinion is because ceremonies and worship services are usually performed not once but often, then it becomes a good habit. Buddhism is a manifestation of their worship of Triratna (Buddha, Dharma, and Sangha) when Buddhists conduct devotional worship based on their true understanding they do not beg for gods, Buddhas or other creatures. Or that is said by Antonius Atosokhi a Parrita concept in the form of reading protection or praying parietal readings to say certain readings to avoid the difficulties protected from evil.

${ }^{20}$ Ahmad Daudy, Kuliah Filsafat Islam, (Jakarta: Bulan Bintang 1986), p. 162.
} 
to those who bow down to him.

You and I are the central points of the universe. But "I" is one. So there is no more "you" and "me". No more subjects and objects. One and only one ... or "l" with the universe. The expanding theory of the universe says that every point in the ever-expanding universe is the center of the universe, every creature in the universe is the focal point from which the universe appears.

\section{Deconstruction of the Divinity}

A doctrine or truth claim seeks to make it completely valid and usable by the times, but it does not go completely smoothly; there are many challenges, criticisms, and obstacles, although not many give the applause of the truth claim which it has brought and then follows it and become a lone exponent. However, the formation of deconstruction is certainly not easy and must go through a chain that at the practical level is always eternal, beyond space and time.

Deconstruction by Derrida is an invention. Derrida reveals that "An invention always presupposes some illegality, the breaking of an implicit contract; it inserts a disorder into the peaceful ordering of things, it disregards the proprieties'. An invention always presupposes some kinds of illegality, a breach of an implicit contract; the invention incorporates an irregularity into the order of harmony of things, the invention ignores the general thing which is assumed to be true. Furthermore, Derrida says, " There is no natural invention-and yet invention also presupposes originality, a relation to origins, generation, procreation, genealogy, that is to say, a set of values often associated with genius or generality, thus with naturality." 21

The chain is a representation of the existence of the falsification form embodied in thesesantithesis, action-reaction and constructionreconstruction or deconstruction, therefore truth will always be a hypo-knowledge that will someday be falsified in a variety of forms with

${ }^{21}$ Derrida, Jacques, Psyche: Invention of the Other, in Derrek Attridge (Ed.), Jacques Derrida: Acts of Literature, (New York: Routledge, 1992), p. 312. the parameters and indicators that accompany it. The indicators are accidental, local, contextual and because the weakness of the radius of truth is grasping an era. For that, the writer will review the concept of the foundation of deconstruction. Deconstruction is a combination of possibilities of two elements placed in contaminating oppositional relations. ${ }^{22}$

The author argues, critique paradigm on theology as a theoretical activity is a deconstruction of thought of the divinity theory that displays various religious theories about God, especially in the deconstruction of divinity (theology) in Islam. It can be said that the process of deconstruction of the theory of God go through several stages that the author arranged based on the basis of a sequential chain. Each other is complementary, interdependent and inseparably based on logic. 1. Supplementation, 2. Contamination, 3. Interpretation (cannot be one sense), 4. Invention (irregularity into the order of harmony) 5. Reoccurrences are rearranged by displaying other logic.

Deconstruction requires, first, a supplement which means 'an addition' and 'a substitution'. Rousseau uses the word "supplement" to describe "writing". "Writing" is an addition. According to Derrida, this supplementation process will continue in language because it is not self-sufficient (incomplete). There is always a process of addition and replacement. The process of addition or replacement does not mean that there is an "original", but because "The supplemental difference within language oscillates between nostalgia for lost unities and a joyful embrace of their loss". ${ }^{23}$ Second, contamination, the boundaries that shape the identity and separate the two elements in the concept cannot be maintained anymore. At certain reading events the result of contamination between the two elements makes a term cannot be decided. Also, this is said by J. Hillis, Miller Gregory. ${ }^{24}$ Thirdly, Derrida's interpretation of

${ }^{22}$ Marcelus Ungkang, "Dekonstruksi Jaques Derrida sebagai Strategi Pembacaan Teks Sastra" Jurnal Pendidikan Humaniora, Vol. 1, No. 1, 2013. pp. 30-37.

$23 \mathrm{~J}$. Hillis, Miller Gregory, The Blackwell Guide to Literary Theory (Malden: Blackwell Publishing, 2007), p. 80.

24 Deconstruction process is done by showing 
thought can be understood by taking into account the steps Tyson demonstrates as well as how these interpretations differ from one to another. to declare that the text cannot be formulated in undecidability. ${ }^{25}$ Fourth is the invention. The concept of Derrida's deconstruction support is an invention. Derrida reveals that "An invention always presupposes some illegality, the breaking of an implicative contract; it inserted the disorder into the ordering of things; it disregards the proprieties' invention always presupposes some kind of illegality, a breach of an implicit contract; the invention incorporates an irregularity into the order of harmony of things, the invention ignores the generally accepted right. ${ }^{26}$ Fifth, re-design in practice, the actual process of re-actualization has taken place during the deconstruction process. The keyword for this process is "production". The reason is an important step to reach the invention in deconstruction reading. The text as a signed network is rearranged by displaying other "other logic," "other messages," or "other text" opened earlier. ${ }^{27}$

The authors argue that, in order to reduce these deconstructive elements, it is necessary to have a methodology that will examine the theory of divine deconstruction. Meta-narration

contamination or interdependence between two elements in binary opposition which becomes the focus of the reading. The contamination can also be done by tracing the element in binary opposition historically by J. Hillis, Miller Gregory, The Blackwell Guide to Literary Theory, (Malden: Blackwell Publishing, 2007), p. 82. As with Derrida's theory of Deconstruction, Jacques. of Grammatology, translation by Gayatri C. Spivak. Baltimore: The John Hopkins University Press, 1976), p. 24. "The movements of deconstruction do not destroy structures from the outside. They are not possible and effective, nor can they take accurate aim, except by inhabiting those structures. Inhabiting them in a certain way, because one always inhabits, and all the more when one does not suspect it. Operating necessarily from the inside, borrowing all the strategic and economic resources of subversion from the old structure, borrowing them structurally, that is to say without being able to isolate their elements and atoms, the enterprise of deconstruction always in a certain way falls prey to its own work ". Deconstruction movement does not destroy the structure from the outside. It is impossible and ineffective, nor can it be targeted, except by taking place within that structure. Occupy it like a parasite: borrow all the strategies and economic subversion sources of the old structure structurally then deconstruct it"

${ }^{25}$ Tyson, Lois, Critical Theory Today: A User-friendly Guide,( New York: Routledge, 2006), p. 259.

${ }^{26}$ Derrida, Jacques, Psyche: Invention of the Other, 1992), p. 313 .

${ }^{27}$ Derrida, Jacques, Psyche: Invention..., p.316 of deconstruction methodology by adopting the theory of research development program Imre Lakatos. The author, in this case, uses Imre Lakatos research program, so it can be said that in this research program there are rules of a methodology called "Heuristic", that is conceptual framework as a systematic consequence. A systematic heuristic framework is a necessity for making discoveries through inductive reasoning and experiments.

In the concept of the Lakatos research program, ${ }^{28}$ there is a basic and basic core (the core of the program), which in turn is not a change in the core of the program (basic, principle) but a protective circle of supporting theories. By borrowing the opinion of Imre Lakatos there are elements that must be known in relation to the research program:

1. The core, this core cannot be rejected or modified.

2. A protective belt consisting of auxiliary hypotheses, this protective hypothesis must withstand various attacks, tests, and obtain adjustments, even changes and alterations in order to maintain the underlying core.

3. A series of theories in which the next theory is the result of the Bantu clause added from the previous theory. ${ }^{29}$

Just as Islam has its main teachings (ushul) (core program) and supporting teaching (furu'). As an example of the implementation of Lakatos research development program approach in Islam is the concept of monotheism. The doctrine that "God is one, is not split," can be placed at the core of the program. Meanwhile, his guardian circle of Quranic verses, hadith aqidah, causality theory, "possible" and "impossible" theory, fitrâh, and relation-dialective theory. This program continues to grow into the concept of aqidah Islamiyah. When there are attacks that want to abort this program, then the first step that must

${ }^{28}$ Imre Lakatos, "Falsification and the Methodology of Research Programmes", in I. Lakatos and A. Musgrave (eds), Criticism and the Growth of Knowledge (Cambridge: Cambridge University Press, 1974), p. 135.

${ }^{29}$ Muhammad Muslih, Filsafat Ilmu, kajian atas asumsi Dasar Paradigma dan Kerangka teori ilmu Pengetahuan, (Yogjakarta: Belukar, 2006), p. 121. 
be done, examine the scholarship of the attacker theory. If it does not work then the protective layer will be idle for "fighting".

\section{DECONSTRUCTION OF THE DIVINITY THEORY}

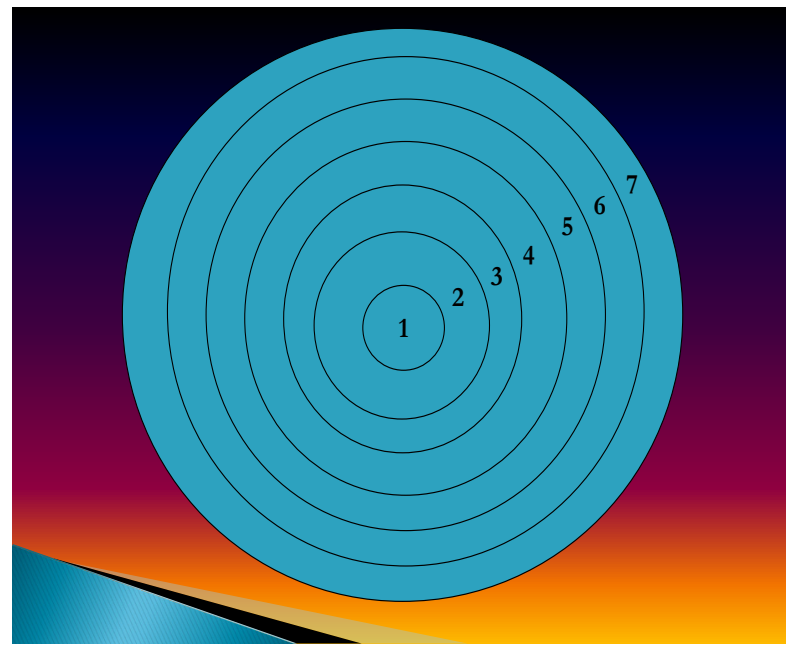

1. The core/doctrine(Tawheed concept) Allah is One

2. Circle of Guard (Holy Quran)

3. A series of theories (Hadiths)

4. Theory of Causality

5. Theory of possible and impossible

6. Theory of Fitrah

7. Theory of relation-dialective.

Analysis of the deconstruction of divinity theory based on Lakatos research program.

1. The Concept of Tawheed

Tawheedis knowledge of testimony, faith, and belief in the unity of God with all his perfection. The concept of monotheism because it discusses the essay of Allah Swt, Islam studied that is about the asma (names) and af'al (acts) God is obligatory, possible and $j a^{\prime} i z^{30}$ Based on the Quran, the unity of God includes three things, i.e. the essence of His being, there is no more than one God and no partner for God; His af'al is One, no one can do the work done by God.

2. Circle of Guard (Holy Book of the Quran) The holy book of Quran as the core protector circle of the program (the concept of

${ }^{30}$ Abdul Razak, Ilmu Kalam, p,13. monotheism) theologically contains the religious values relating to divinity (tawheed, and miracles) because these three are central to Islamic religious development research throughout the earth. Many real and reallife stories are attitudes of the prophet's opponents and his teachings that are unable to break through, alter and the renegade the holy book of the Quran. Islamic thinking is so logical that it is not difficult to understand and believe in its truth. ${ }^{31}$

The most important statement in the Quran is to the absolute essence of God. God commands all things, great or small. The universe is a single plan created by his knowledge and the wisdom of a single creator and mover. ${ }^{32}$ Thus Almighty God will always cultivate, develop, educate, nurture, endure, repair, collect, prepare, lead, direct, and complete. In connection with the discussion into the Unity in the Quran can be explained that is a lively and deadly substance.

3. A Series of Hadith Theories

The position of the Prophet's Hadith as the authoritative source of the second Islamic doctrine has been accepted by almost all the scholars and Muslims, not only among the Sunni but also among Shi'ites and other Islamic schools. The legitimacy of this authority is not achieved by the Muslim community's recognition of the Prophet as powerful but acquired by the will of the Divine. ${ }^{33}$

Based on the context mentioned above, it can be said that the hadith or Sunna of the Prophet is the second source of Islamic teachings in addition to the Quran. There are those who reject the hadith as a source of Islamic teachings, meaning that people essentially reject the Quran. There are some

31 Muhammad A. Khalafullah, Alqur'an Bukan Kitab Sejarah, (Jakarta: Paramadina, 2002), p. 85. The original book title, Al-Fanna al-Qashashi fil al-Qur'an al-Karim (London-BeirutCairo: Sina li al-Intisyar al-Arabi, 1999)

${ }_{32}$ M. Dawam Rahajo, Insanul Kamil Konsepsi Manusia menurut Islam, (Jakarta: Grafiti Pers,1987), p.75.

${ }_{33}$ Azami, Studies in Hadith Methodology and Literature, (Indianapolis: American Trust Publications, 1977), p. 5. 
who reject the hadith as a source of Islamic teachings both among Muslims and nonMuslims. They generally understand that the existence of the authority of the Prophet as revealed by the Quran refers to the Prophet's words. ${ }^{34}$

4. Theory of Causality (due to the effect)

God is the only eye, the other is new and made by Him. Therefore, God is the true creator of being and the turn of the generation is a pure creation; in that creation, God makes each one of them not directly. 35

5. Theory of Possible and Impossible

A form which is possible or a form which is real because of the others (wajîbul wujûd li ghairihi) is like a form of light that would not exist if there were no suns. The light itself according to its nature can be manifest and can be intangible. If he does not exist then the others will not exist at all. It is the first cause of all beings. The obligatory being is called God (Allah). ${ }^{36}$

According to the Osman Raliby, the unity of God is: God is one in His substance. God's omnipresence in His substance can be formulated in the words that God's substance is not the same and cannot be equated with anything. God's substance will not die but will be eternal and eternal. God is also a mandatory being, meaning only God is eternal and eternal His being. Besides Allah, everything is mukminul wujûd, meaning it can exist and may not exist.

6. Theory of Fitrah

Man is the most perfect creature and the best of creation that is equipped with the mind of thought. Ibn 'Arabi, for example, describes the nature of man by saying that "no Gods' creatures are better than men, who have the power to live, know, will, speak, see,

34 See for example Mustafa al-Sibai, al-Sunnah wa Makanutuha fi Tasyri al-Islamy, (Cairo: Dar al-Qaumiyat li alTibaat wa al-Nasyr, 1966), p. 55-59; Muhammad Abu Zahrah, Ushul al-Figh, (t.tp. Dar al-Fikr all-Arabi, t.th.), 106-107. Specifically about the orientalist view of this matter can be read for example from the explanation of Fazlur Rahman in his book Islam, (Chicago: University of Chicago Pres, 1979), p. 5.

${ }^{35}$ Hanafi, Pengantar Filsafat Islam, p. 187.

${ }^{36}$ Hanafi, Pengantar..., p.98. hear, think and decide. The harmony of the two aspects with a number of potentials delivers men as unique and special, perfect, and deferential God's creature. Thus, human nature is the creature of God, so man comes from God. ${ }^{37}$

7. Relations-Dialective Theories.

The philosophical and anthropological vision that Allah has claimed in the Quran has occupied man in this universe into two main functions, namely as chalifa (leader) and ' $a b d$ (obedient). Such a categorical view does not imply a dualism-dichotomy notion, but it explains the functional content that humans must carry in performing the historical tasks of their life on earth. With the concept of the caliph, it is not intended to contrast it with the concept of ' $a b d$, but both must be placed as an inseparable unity. Both of them have a dialectical relation that will lead man to the peak of his human existence. ${ }^{38}$

\section{The vision of the Philosophy of the Deconstruction Theory of Godhead}

Different views that want to change the core of the divine (tawheed) program in Islam, among others are Judaism, Christianity, Hinduism, Buddhism and even among Islam itself, experience a stagnation. Likewise in Islam itself, the core problem about tawheed is final and no one disagrees. What distinguishes is the way, the process even, the practice of worship, the interpretation of the divinity that leads to various prolonged polemic. Is it among kalâm (Islamic theology) scholars, among tassawuf, the flow of Islam, Islamic organizations (Muhammadiyah, NU, LDII, Persis, etc) whether Islam, abangan, moderate, orthodox, or contemporary? All of these are to spread the Oneness which has developed from the time of the Prophet PBUH until today. The attacks against Islam in the framework of separating Muslims from the framework of tawheed, various ways are done

37 Ahmad Tafsir, Filsafat Pendidikan Islam, Integrasi Jasmani, Rohani dan Kalbu Memanusiakan Manusia, (Bandung: Rosda Karya, 2010), p.14.

${ }^{38}$ Samsul Nizar, M.A, Filsafat Pendidikan Islam Pendekatan Histori, Teoritis dan Praktis, (Jakarta: Ciputat Pers, 2002) p. 20. 
to immerse Islam from the face of the earth. If fought, all Muslims will unite to defend the Tawheed.

If Islam, as the religion of rahmatan lil 'alamîn, is in subtle combat in order to separate the teachings of tawheed with from its believers, then it is possible that the tawheed will gradually fade from the Muslims. This phenomenon has been felt in the present era through culture, that western cultures enter the Muslim world in a way that does not feel. That culture will gradually influence and separate Muslims from their tawheed.

For centuries, Islam was seen as another and a dangerous enemy for the Christian West. Edwar Said asserts that "For the West, Asia was once seen as a distant and alien, Islam as an enemy of Western European Christianity". ${ }^{39}$ Christian West with the concept of orientalism is not only a positive doctrine of the east that is always present in the west as well as negative doctrine, orientalism as an academic tradition that is very influential on the field of science and also a collection, ideas of belief, clichés or knowledge of the east with schools of thought within culture.

It should be admitted that the existence of the orientalists both in terms of history and philosophy that some of the orientalists have spent part of their age, power or ability to learn Islam. Unfortunately, in the scientific studies, the orientalists are looking for ugliness and weakness of Islam, Islamic culture and Islamic history that they deliberately expressed in their books and certain political and religious goals. ${ }^{40}$ As Renan was a Frenchman, he declared that the creed of tawheed in Islam is a creed that confuses and demeans human dignity. ${ }^{41}$

The characteristics of orientalists have a vision and mission and innovation, so that Muslims let go of their religious teachings and turn Muslims away from the teaching, and want

${ }^{39}$ Mark R. Woodward, Jalan Baru Islam, (Bandung:Mizan, 1998), p. 29.

${ }^{40}$ Bey Arifin, Islam Dan Para Orientalisme, (Surabaya: Bina Ilmu, 1983), p. 45.

${ }^{41}$ Muhammad Al Bahiy, Pemikiran Islam Modern, (Jakarta: PustakaPanjimas 1986), p 4. the collapse of the glory of Islam from the world. On the other hand, though the writers of modern orientalism have tried to be more polite and objective in their approach to Islam, names like Gibb, Watts, and Smith. ${ }^{42}$

The doctrine (tawheed) in Islam is built in the world as a great tradition for fair and noble acts. The doctrine blows into the human spirit of generosity and generosity as well as easy to execute and have the characteristics of humanity. The Islamic doctrine establishes a society in which there is rarely apostasy to divinity and kufr as in other societies that precede it.

\section{Conclusion}

God does not need additional qualities and values for His perfection but the creatures need and be dependent on the field of being, the divine field and divine attributes for the ride of manifestation. Al-ilâh is: who is adored with great love; bowing to him, humbling himself before him, fearing and expecting him, a place of resignation when in difficulty, praying and putting his trust in him for his own good, pleading for his protection, and creating a calm in remembering him and being in love with him.

The doctrine or truth claim seeks to make it completely valid and usable by the times, yet it does not go completely smoothly. There are many challenges, criticisms, and obstacles, although few applaud the claims of truth that has been brought and then follow it and become obedient. However, the formation of deconstruction is certainly not easy and must go through a chain that at the practical level is always eternal, beyond space and time.

Reducing deconstruction elements needs a methodology that will cover the theory of divine deconstruction. Meta-narration of deconstruction methodology by adopting the theory of research development program of Imre Lakatos. The writer, in this case, uses Imre Lakatos research program, so it can be said that in this Research Program there are rules of a methodology called "Heuristic", that is conceptual framework as a

${ }^{42}$ Taufik Abdullah, Metodologi Penelitian Agama, (Jogjakarta: Tiara Wacana, 1990), 2nd print, p. 31. 
systematic consequence. A systematic heuristic framework is a necessity for making discoveries through inductive reasoning and experiments.

The implementation of Lakatos' research development program approach in Islam is the concept of monotheism. The doctrine that "God is one, is not split," can be placed as the core of the program. The core of the program/doctrine (the Concept of God) is the One, while the protective circle (Scripture of the Quran) to deal with forms of attack, criticism, destruction and supported by a Series of Theories (Hadiths), theory of Causality, theory of Possible and Impossible, theory of Fitrah and Relation-Dialective. Different views that want to change the core of the divine (tawheed) program in Islam, among others are Judaism, Christianity, Hinduism, Buddhism and even among Islam itself, experience a stagnation. Likewise in Islam itself, the core problem about tawheed is final and no one disagrees. What distinguishes is the way, the process even, the practice of worship, the interpretation of the divinity that leads to various prolonged polemic. However, Islam still keeps strong.

\section{References}

Abdullah, Taufik, Metodologi Penelitian Agama, Yogyakarta: Tiara Wacana, 1990.

Almakin, Nabi-Nabi Nusantara Kisah Lia Eden dan Lainnya, Yogyakarta: Suka Press, 2017.

Arifin, Bey, Islam Dan Para Orientalisme, Surabaya: Bina Ilmu, 1983.

Atosokhi, Antonius Gea et.al, Relasi dengan Tuhan, Jakarta: Elex Media Komputindo, 2004.

Bahiy, Muhammad, al-, Pemikiran Islam Modern, Jakarta: Pustaka Panjimas, 1986.

Bakker, Anton, Metode-Metode Filsafat, Jakarta, Ghalia Indonesia, 1984.

Cundamani, Bagaimana Umat Hindu Menghayati Ida Sanghyang Widhi, Jakarta: Departmen Agama RI, 1990.

Daudy, Ahmad, Kuliah Filsafat Islam, Jakarta: Bulan Bintang 1986.

Departemen Agama Republik Indonesia, Alqur'an dan terjemahannya, Jakarta: Yayasan penerjemah, 1974.

Derrida, Jacques, Pysche: Invention of the Other. In Derrek Atridge (Ed.), Jacques Derrida: Acts of Literature, New York: Routledge, 1992.

, Of Grammatology, translated by. Gayatri

C. Spivak. Baltimore: The John Hopkins University Press, 1976

Dzakiey, Bakran, Hamdani, adz-, Psikoterapi dan Konseling Islam, Yogyakarta; Fajar Pustakabaru, 2001.

, Prophetic Intelegence Kecerdasan Kenabian, Menumbuhkan Potensi Hakiki Insan Melalui Pengembangan Kesehatan Rohani, Yogyakarta: Banguntapan Bantul, 2013.

Engkus. Kuswarno, Metodelogi Penelitian Fenomenologi, Konsepsi, Pedoman dan Contoh Penelitian, Bandung: Widia Padjajaran, 2009. Hanafi, Pengantar Filsafat Islam, Jakarta: Bulan Bintang, 1969.

Herdiansyah, Haris, Metodologi Penelitian Kualitatif Untuk IImu-IImu Sosial, Jakarta Selatan: Salemba Humanika, 2012.

Imaduddin, Muhammad and Abdulrahim, Kuliah Tauhid, Bandung: Pustaka-Perpustakaan Salman ITB, 1980.

Kaaf, Zakiy Abddullah, al-, Menyingkap rahasia Isra'-Mi'raj Rasulullah Saw, Bandung: Pustaka Setia, 2012.

Kaelan, Metodologi Penelitian Kualitatif bidang Filsafat, Yogyakarta: Paradigma, 2006.

Khalafullah, Muhammad A, Alqur'an Bukan Kitab Sejarah, Jakarta: Paramadina, 2002.

Lakatos, Imre, Falsification and the Methodology of Research Programmes, in I. Lakatosdan A. Musgrave (eds), Criticism and the Growth of Knowledge, Cambridge: Cambridge University Press, 1974.

Marcelus Ungkang, "Dekonstruksi Jaques Derrida sebagai Strategi Pembacaan Teks Sastra" Jurnal Pendidikan Humaniora, Vol. 1, No. 1, 2013. Doi 10.17977/jph.v111.3919

Miller, Hillis, Gregory, The Blackwell Guide to Literary Theory, Malden: Blackwell Publishing, 2007.

Muslih, Muhammad, Filsafat IImu, kajian atas Asumsi Dasar Paradigma dan Kerang kategori ilmu Pengetahuan, Yogyakarta: Belukar, 2006.

Nazir, M., Metode Penelitian Kualitatif, Jakarta: Ghalia Indonesia, 1988.

Nizar, Samsul, Filsafat Pendidikan Islam Pendekatan Histori, Teoritis dan Praktis, Jakarta: Ciputat Pers, 2002. 
Noor, J., Metodologi Penelitian Skripsi, Tesis, Disertasi, dan Karya Ilmiah, Jakarta: Kencana, 2011.

Qardawi, Yusuf Tauhid dan Fenomena Kemusyrikan, Haqiqat Al-Tauhid translated by. H. Abd. Rahim Haris, Jakarta: Pustaka Darul Hikmah, 2001.

Qarni, Aidh, al-, La Tahzan, Jangan bersedih, Jakarta, Qisthi Pres, 2014.

Qutub, Koreksi atas pemahaman La Ilahallla Allah, translated by. Yudian Wahyudi Asmin, Yogyakarta; al-Kautsar, 1989.

Rahajo, Dawam, Insanul Kamil Konsepsi Manusia menurut Islam, Jakarta: Grafiti Pers,1987.

Razak, Abdul, Rosihan Anwar, Ilmu Kalam untuk UIN, STAIN PTAIS, Bandung: Pustaka Setia, 2001.

Soejono Soemargono, Pengantar Filsafat, Yogyakarta: Tiara Wacana Yogya,1996.

Sugiyono, Metode Penelitian Kuantitatif, Kualitatif, Bandung: Alfabeta, 2009.

Suseno, Franz Magnis, Menalar Tuhan, Yogyakarta: Kanisius, 2006.
Tafsir, Ahmad, Filsafat Pendidikan Islam, Integrasi Jasmani, rohani dan Kalbu memanusiakan manusia, Bandung: Rosda Karya, 2010.

Tyson, Lois, Critical Theory Today: A User-friendly Guide, New York: Routledge, 2006.

Ungkang, Marcelus "DekonstruksiJaques Derrida sebagai Strategi Pembacaan Teks Sastra" Jurnal Pendidikan Humaniora, Vol 1, No 1, 2013.

Wijaya, Krisnanda-Mukti, Wacana Budda-Dharma, Jakarta: Yayasan Dharma Pembangunan, 2003.

Woodward, Mark R ,Jalan Baru Islam, Bandung: Mizan, 1998.

Wowor, Cornelis, Ketuhanan Yang Maha Esa dalam Agama Budha, Jakarta: Akademi Buddhis Nalanda, 1984.

Zuberi, Achmad Charris, and Anton, Metodologi Penelitian Filsafat, Yogyakarta: Kanisius, 1990. 